\title{
Potent, Selective Pyrone-Based Inhibitors of
}

\section{Stromelysin-1}

David T. Puerta, John Mongan, Ba L. Tran, J. Andrew McCammon, and Seth M. Cohen*

Department of Chemistry and Biochemistry, Howard Hughes Medical Institute,

Department of Pharmacology, Bioinformatics Program, and Center for Theoretical

Biological Physics, University of California, San Diego, La Jolla, California 92093

\section{Supporting Information}

*Author to whom correspondence should be addressed. Telephone: (858) 822-5596.

FAX: (858) 822-5598. E-mail: scohen@ucsd.edu. 
General. Unless otherwise noted, starting materials were obtained from commercial suppliers and used without further purification. Elemental analysis was performed at NuMega Resonance Labs, San Diego, California. ${ }^{1} \mathrm{H} /{ }^{13} \mathrm{C}$ NMR spectra were recorded on a Varian FT-NMR spectrometer running at 300 or $400 \mathrm{MHz}$ at the Department of Chemistry and Biochemistry, University of California, San Diego. Mass spectra were acquired at the Small Molecule Mass Spectrometry Facility located in the Department of Chemistry and Biochemistry, University of California, San Diego. A ThermoFinnigan MAT 900XL mass spectrometer was used to acquire the data for the high resolution mass spectra (HRMS). The HRMS spectra were obtained with fast atom bombardment (FAB) as the ion source with 3-nitrobenzylalcohol as the matrix and polyethylene glycol as a reference.

2-Carboxy-3-benzyloxy-6-methyl-pyran-4(1H)-one (1). Compound 1 was synthesized according to a literature procedure (Z.D. Liu, S. Piyamongkol, D.Y. Liu, H.H. Khodr, S.L. Lu, R.C. Hider, Bioorg. Med. Chem. 2001, 9, 563).

3-Benzyloxy-6-methyl-pyran-4(1H)-one-2-carboxy-N-(4-iodobenzylamide) (2). To a suspension of $\mathbf{1}(2.4 \mathrm{~g}, 9.4 \mathrm{mmol})$ in dry THF $(100 \mathrm{~mL})$ was added $N$ hydroxysuccinamide (NHS) (1.1 g, $9.4 \mathrm{mmol})$ and stirred at room temperature under $\mathrm{N}_{2}$ (g) for $30 \mathrm{~min}$. 1,3-Dicyclohexylcarbodiimide (DCC) (1.9 g, $9.4 \mathrm{mmol}$ ) was then added and the reaction was stirred at room temperature under $\mathrm{N}_{2}(\mathrm{~g})$ for $3 \mathrm{~h}$. The N,Ndicyclohexylurea (DCU) was filtered and to the resulting filtrate was added 4iodobenzylamine $(2.2 \mathrm{~g}, 9.4 \mathrm{mmol})$ as a solid. The reaction was stirred overnight under 
$\mathrm{N}_{2}(\mathrm{~g})$ at $60{ }^{\circ} \mathrm{C}$. The solvent was removed by evaporation and the residue was taken up in $\mathrm{CHCl}_{3}$. The compound was purified by silica column chromatography $\left(\mathrm{CHCl}_{3}\right)$ to yield a white solid $(3 \mathrm{~g}, 67 \%) .{ }^{1} \mathrm{HNMR}\left(\mathrm{CDCl}_{3}, 300 \mathrm{MHz}, 25^{\circ} \mathrm{C}\right): \delta 2.37\left(\mathrm{~s}, 3 \mathrm{H}\right.$, pyrone- $\left.\mathrm{CH}_{3}\right)$, $4.33(\mathrm{~d}, J=6.0 \mathrm{~Hz}, 2 \mathrm{H}), 5.34\left(\mathrm{~s}, 2 \mathrm{H}\right.$, benzyl- $\left.\mathrm{CH}_{2}\right), 6.29(\mathrm{~s}, 1 \mathrm{H}$, pyrone-H), $6.89(\mathrm{~d}, J=$ $8.4 \mathrm{~Hz}, 2 \mathrm{H}), 7.30(\mathrm{~m}, 5 \mathrm{H}), 7.60(\mathrm{~d}, J=8.4 \mathrm{~Hz}, 2 \mathrm{H}), 8.07$ (br, $1 \mathrm{H}$, amide-H). ${ }^{13} \mathrm{CNMR}$ $\left(\mathrm{CDCl}_{3}, 100 \mathrm{MHz}, 2{ }^{\circ} \mathrm{C}\right): \quad \delta 20.1,43.2,75.3,94.2,115.3,128.7,128.9,129.0,129.7$, 135.0, 136.7, 137.6, 145.9, 165.6, 175.8. ESI-MS(+): $m / z 497.94[\mathrm{M}+\mathrm{Na}]^{+}$.

\section{3-Benzyloxy-6-methyl-pyran-4(1H)-one-2-carboxy-N-(4-biphenylamide) (AM-1P).}

To a suspension of $1(250 \mathrm{mg}, 0.95 \mathrm{mmol})$ in dry THF $(25 \mathrm{~mL})$ was added NHS (110 mg, $0.95 \mathrm{mmol}$ ) and stirred at room temperature under $\mathrm{N}_{2}(\mathrm{~g})$ for $30 \mathrm{~min}$. DCC (200 mg, 0.95 mmol) was then added and the reaction was stirred at room temperature under $\mathrm{N}_{2}(\mathrm{~g})$ for 3 h. The DCU was removed by filtration, and to the resulting filtrate was added 4biphenylamine (161 $\mathrm{mg}, 0.95 \mathrm{mmol})$ as a solid. The reaction was stirred for six days under $\mathrm{N}_{2}(\mathrm{~g})$ at room temperature. The solvent was removed by evaporation and the residue was taken up in $\mathrm{CHCl}_{3}$. The compound was purified by silica column chromatography $\left(\mathrm{CHCl}_{3}\right.$ with $\left.0-1 \% \mathrm{MeOH}\right)$ to yield a white solid $(150 \mathrm{mg}, 38 \%)$.

${ }^{1} \mathrm{HNMR}\left(\mathrm{CDCl}_{3}, 400 \mathrm{MHz}, 2{ }^{\circ} \mathrm{C}\right): \delta 2.38\left(\mathrm{~s}, 3 \mathrm{H}\right.$, pyrone- $\left.\mathrm{CH}_{3}\right), 5.50(\mathrm{~s}, 2 \mathrm{H}$, benzyl$\left.\mathrm{CH}_{2}\right), 6.31(\mathrm{~s}, 1 \mathrm{H}$, pyrone-H), $7.25(\mathrm{~d}, J=8.8 \mathrm{~Hz}, 2 \mathrm{H}), 7.34(\mathrm{~m}, 1 \mathrm{H}), 7.41(\mathrm{~m}, 4 \mathrm{H}), 7.47$ (m, 4H), $7.56(\mathrm{~m}, 3 \mathrm{H}), 9.78\left(\mathrm{br}, 1 \mathrm{H}\right.$, amide-H). ${ }^{13} \mathrm{CNMR}\left(\mathrm{CDCl}_{3}, 100 \mathrm{MHz}, 25{ }^{\circ} \mathrm{C}\right): \delta$ 20.1, 76.3, 115.4, 120.0, 126.7, 127.1, 127.4, 128.7, 129.0, 129.3, 129.4, 135.0, 136.1, 137.6, 140.1, 146.1, 156.4, 165.7, 175.7. $\quad$ ESI-MS(+): $m / z 434.04[\mathrm{M}+\mathrm{Na}]^{+} . \quad$ HRFABMS Calcd for $\mathrm{C}_{26} \mathrm{H}_{22} \mathrm{NO}_{4}$ : 412.1543 . Found: 412.1547 . 
To a solution of AM-1P (100 mg, $0.24 \mathrm{mmol})$ in methanol (100 mL) was added 10\% $\mathrm{Pd} / \mathrm{C}(10 \mathrm{mg}, 10 \% \mathrm{w} / \mathrm{w})$. The reaction was placed under $\mathrm{H}_{2}(\mathrm{~g})$ at $35 \mathrm{psi}$ for $12 \mathrm{~h}$. The catalyst was removed by filtration, and the resulting filtrate was evaporated to an offwhite solid and recrystallized from EtOH (60 mg, 77\%). ${ }^{1} \mathrm{HNMR}\left(d^{3}-\mathrm{MeOD}, 300 \mathrm{MHz}\right.$, $\left.25{ }^{\circ} \mathrm{C}\right): \delta 2.46\left(\mathrm{~s}, 3 \mathrm{H}\right.$, pyrone- $\left.\mathrm{CH}_{3}\right), 6.39(\mathrm{~s}, 1 \mathrm{H}$, pyrone-H), $7.34(\mathrm{~m}, 1 \mathrm{H}), 7.43(\mathrm{t}, J=7.2$ $\mathrm{Hz}, 2 \mathrm{H}), 7.64(\mathrm{t}, J=8.1 \mathrm{~Hz}, 4 \mathrm{H}), 7.80(\mathrm{~d}, J=8.7 \mathrm{~Hz}, 2 \mathrm{H}) .{ }^{13} \mathrm{CNMR}\left(\mathrm{CDCl}_{3}, 100 \mathrm{MHz}\right.$, $\left.25^{\circ} \mathrm{C}\right): \quad \delta 20.5,112.6,120.8,126.8,127.3,127.7,128.7,135.3,135.7,140.0,147.2$ 155.4, 165.2, 175.7. ESI-MS(+): $m / z 322.06[\mathrm{M}+\mathrm{H}]^{+}$. Anal. Calcd for $\mathrm{C}_{19} \mathrm{H}_{15} \mathrm{NO}_{4}: \mathrm{C}$, 69.76; H, 5.27; N, 4.07. Found C, 69.54; H, 5.48; N, 4.30.

\section{3-Benzyloxy-6-methyl-pyran-4(1H)-one-2-carboxy-N-(4-phenylbenzylamide)}

(AM-2P). To a suspension of 1 (700 mg, $2.7 \mathrm{mmol})$ in dry THF (40 mL) was added NHS (310 mg, $2.7 \mathrm{mmol}$ ) and stirred at room temperature under $\mathrm{N}_{2}(\mathrm{~g})$ for $30 \mathrm{~min}$. DCC (557 $\mathrm{mg}, 2.7 \mathrm{mmol}$ ) was then added and the reaction was stirred at room temperature under $\mathrm{N}_{2}(\mathrm{~g})$ for $3 \mathrm{~h}$. The DCU was removed by filtration, and to the resulting filtrate was added 4-phenylbenzylamine $(495 \mathrm{mg}, 2.7 \mathrm{mmol})$ as a solid. The reaction was stirred overnight under $\mathrm{N}_{2}(\mathrm{~g})$ at room temperature. The solvent was removed by evaporation and the residue was taken up in $\mathrm{CHCl}_{3}$. The compound was purified by silica column chromatography $\left(\mathrm{CHCl}_{3}\right.$ with $\left.0-1 \% \mathrm{MeOH}\right)$ to yield a white solid (800 $\mathrm{mg}, 90 \%$ ). ${ }^{1} \mathrm{HNMR}\left(d^{6}\right.$-DMSO, $\left.400 \mathrm{MHz}, 25{ }^{\circ} \mathrm{C}\right): \delta 2.29\left(\mathrm{~s}, 3 \mathrm{H}\right.$, pyrone- $\left.\mathrm{CH}_{3}\right), 4.45(\mathrm{~d}, J=6.0 \mathrm{~Hz}$, 2H), $5.15\left(\mathrm{~s}, 2 \mathrm{H}\right.$, benzyl- $\left.\mathrm{CH}_{2}\right), 6.38(\mathrm{~s}, 1 \mathrm{H}$, pyrone-H), $7.35(\mathrm{~m}, 8 \mathrm{H}), 7.46(\mathrm{t}, J=7.4 \mathrm{~Hz}$, 
2H), $7.57(\mathrm{~d}, J=8.4 \mathrm{~Hz}, 2 \mathrm{H}), 7.62(\mathrm{~d}, J=8.4 \mathrm{~Hz}, 2 \mathrm{H}), 9.12(\mathrm{t}, J=5.6 \mathrm{~Hz}, 1 \mathrm{H}$, amide-H).

${ }^{13} \mathrm{CNMR}\left(d^{6}\right.$-DMSO, $\left.100 \mathrm{MHz}, 25{ }^{\circ} \mathrm{C}\right): \delta 19.1,42.2,73.4,114.5,126.4,126.5,127.2$, $127.9,128.0,128.1,128.3,128.7,136.1,137.4,138.7,139.6,143.4,149.0,158.6,165.1$, 175.1. ESI-MS(+): $m / z 448.07[\mathrm{M}+\mathrm{Na}]^{+}$. HR-FABMS Calcd for $\mathrm{C}_{27} \mathrm{H}_{24} \mathrm{NO}_{4}: 426.1700$. Found: 426.1702.

\section{3-Hydroxy-6-methyl-pyran-4(1H)-one-2-carboxy-N-(4-phenylbenzylamide) (AM-}

2). To a solution of AM-2P (100 mg, $0.24 \mathrm{mmol})$ in methanol $(100 \mathrm{~mL})$ was added $10 \%$ $\mathrm{Pd} / \mathrm{C}(10 \mathrm{mg}, 10 \% \mathrm{w} / \mathrm{w})$. The reaction was placed under $\mathrm{H}_{2}(\mathrm{~g})$ at $35 \mathrm{psi}$ for $12 \mathrm{~h}$. The catalyst was removed by filtration, and the resulting filtrate was evaporated to an offwhite solid (60 mg, 76\%). ${ }^{1} \mathrm{HNMR}\left(d^{6}\right.$-DMSO, $\left.400 \mathrm{MHz}, 25^{\circ} \mathrm{C}\right): \delta 2.31$ (s, $3 \mathrm{H}$, pyrone$\left.\mathrm{CH}_{3}\right), 4.53(\mathrm{~d}, J=6.4 \mathrm{~Hz}, 2 \mathrm{H}), 6.33$ (s, 1H, pyrone-H), 7.35 (t, $\left.J=7.4 \mathrm{~Hz}, 1 \mathrm{H}\right), 7.43$ (q, $J$ $=10.8 \mathrm{~Hz}, 4 \mathrm{H}), 7.63(\mathrm{~d}, J=10.4 \mathrm{~Hz}, 4 \mathrm{H}), 9.35\left(\mathrm{t}, J=6.2 \mathrm{~Hz}, 1 \mathrm{H}\right.$, amide-H). ${ }^{13} \mathrm{CNMR}$ $\left(d^{6}\right.$-DMSO, $\left.100 \mathrm{MHz}, 25^{\circ} \mathrm{C}\right): \quad \delta 19.4,42.0,112.5,126.4,126.5,127.2,127.9,128.7$, 136.0, 137.4, 138.8, 139.6, 147.3, 162.5, 164.5, 173.3. APCI-MS(+): $m / z 335.95$ $[\mathrm{M}+\mathrm{H}]^{+}$. Anal. Calcd for $\mathrm{C}_{20} \mathrm{H}_{17} \mathrm{NO}_{4}:$ C, 71.63; H, 5.11; N, 4.18. Found $\mathrm{C}, 71.27 ; \mathrm{H}$, $5.43 ; \mathrm{N}, 4.56$.

\section{3-Benzyloxy-6-methyl-pyran-4(1H)-one-2-carboxy-N-[2-(4-biphenyl)ethylamide)]}

(AM-3P). To a suspension of $1(297 \mathrm{mg}, 1.1 \mathrm{mmol})$ in dry THF $(25 \mathrm{~mL})$ was added NHS (131 mg, $1.1 \mathrm{mmol}$ ) and stirred at room temperature under $\mathrm{N}_{2}(\mathrm{~g})$ for $30 \mathrm{~min}$. DCC (236 mg, $1.1 \mathrm{mmol}$ ) was then added and the reaction was stirred at room temperature under $\mathrm{N}_{2}(\mathrm{~g})$ for $3 \mathrm{~h}$. The DCU was removed by filtration, and to the resulting filtrate was 
added 2-(4-biphenyl)ethylamide) $(217 \mathrm{mg}, 1.1 \mathrm{mmol})$ as a solid. The reaction was stirred overnight under $\mathrm{N}_{2}(\mathrm{~g})$ at room temperature. The solvent was removed by evaporation and the residue was taken up in $\mathrm{CHCl}_{3}$. The compound was purified by silica column chromatography $\left(\mathrm{CH}_{2} \mathrm{Cl}_{2}\right)$ to yield a white solid $(450 \mathrm{mg}, 90 \%) .{ }^{1} \mathrm{HNMR}\left(\mathrm{CDCl}_{3}, 300\right.$ $\left.\mathrm{MHz}, 25^{\circ} \mathrm{C}\right): \delta 2.29\left(\mathrm{~s}, 3 \mathrm{H}\right.$, pyrone- $\left.\mathrm{CH}_{3}\right), 2.72(\mathrm{t}, J=6.9 \mathrm{~Hz}, 2 \mathrm{H}), 3.50(\mathrm{q}, J=6.9 \mathrm{~Hz}$, 2H), $5.25\left(\mathrm{~s}, 2 \mathrm{H}\right.$, benzyl- $\left.\mathrm{CH}_{2}\right), 6.23(\mathrm{~s}, 1 \mathrm{H}$, pyrone- $\mathrm{H}), 7.20(\mathrm{~m}, 4 \mathrm{H}), 7.30(\mathrm{~m}, 4 \mathrm{H}), 7.40$ (t, $J=6.9 \mathrm{~Hz}, 2 \mathrm{H}), 7.53$ (t, $J=6.5 \mathrm{~Hz}, 4 \mathrm{H}), 7.83\left(\mathrm{t}, J=5.1 \mathrm{~Hz}, 1 \mathrm{H}\right.$, amide-H). ${ }^{13} \mathrm{CNMR}$ $\left(\mathrm{CDCl}_{3}, 100 \mathrm{MHz}, 2{ }^{\circ} \mathrm{C}\right): \delta 22.0,36.7,43.1,75.0,117.2,128.8,129.1,129.2,130.6$, 130.7, 130.9, 131.0, 131.1, 137.2, 139.4, 141.4, 142.5, 147.6, 148.4, 160.8, 167.5, 177.9. ESI-MS(+): $m / z 462.10[\mathrm{M}+\mathrm{Na}]^{+}$.

\section{3-Hydroxy-6-methyl-pyran-4(1H)-one-2-carboxy-N-[2-(4-biphenyl)ethylamide)]}

(AM-3). To a suspension of AM-3P (300 $\mathrm{mg}, 0.68 \mathrm{mmol})$ in methanol $(50 \mathrm{~mL})$ was added $10 \% \mathrm{Pd} / \mathrm{C}(30 \mathrm{mg}, 10 \% \mathrm{w} / \mathrm{w})$. The reaction was placed under $\mathrm{H}_{2}(\mathrm{~g})$ at $35 \mathrm{psi}$ for $12 \mathrm{~h}$. The catalyst was removed by filtration, and the resulting filtrate was evaporated to an off-white solid (205 mg, 86\%). ${ }^{1} \mathrm{HNMR}\left(\mathrm{CDCl}_{3}, 400 \mathrm{MHz}, 25^{\circ} \mathrm{C}\right): \quad \delta 2.31(\mathrm{~s}, 3 \mathrm{H}$, pyrone- $\left.\mathrm{CH}_{3}\right), 3.00(\mathrm{t}, J=7.2 \mathrm{~Hz}, 2 \mathrm{H}), 3.75(\mathrm{q}, J=6.8 \mathrm{~Hz}, 2 \mathrm{H}), 6.26(\mathrm{~s}, 1 \mathrm{H}$, pyrone-H), 6.89 (br, 1H, amide-H), 7.35 (m, 3H), 7.45 (t, $J=7.2 \mathrm{~Hz}, 2 \mathrm{H}), 7.59$ (d, $J=6.8 \mathrm{~Hz}, 4 \mathrm{H})$.

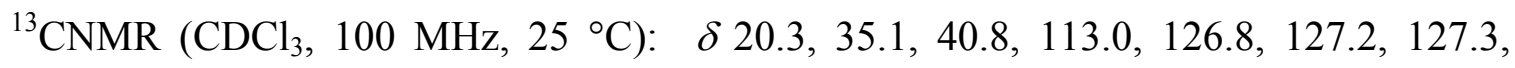
128.7, 129.0, 133.3, 136.9, 137.1, 137.3, 139.6, 140.4, 182.0. HR-FABMS Calcd for $\mathrm{C}_{21} \mathrm{H}_{20} \mathrm{NO}_{4}$ : 350.1387. Found 350.1379. Anal. Calcd for $\mathrm{C}_{21} \mathrm{H}_{19} \mathrm{NO}_{4} \bullet 0.20 \mathrm{H}_{2} \mathrm{O}$ : C, 71.46; H, 5.54; N, 3.97. Found C, 71.31; H, 5.66; N, 4.34. 


\section{3-Benzyloxy-6-methyl-pyran-4(1H)-one-2-carboxy-N-(4-methoxybenzylamide)}

(AM-4P). To a suspension of 1 (515 mg, $1.98 \mathrm{mmol})$ in dry THF (40 mL) was added NHS (228 mg, $1.98 \mathrm{mmol}$ ) and stirred at room temperature under $\mathrm{N}_{2}(\mathrm{~g})$ for $30 \mathrm{~min}$. DCC (409 $\mathrm{mg}, 1.98 \mathrm{mmol}$ ) was then added and the reaction was stirred at room temperature under $\mathrm{N}_{2}(\mathrm{~g})$ for $3 \mathrm{~h}$. The DCU was removed by filtration, and to the resulting filtrate was added 4-methoxybenzylamine) $(271 \mathrm{mg}, 260 \mu \mathrm{L}, 1.98 \mathrm{mmol})$ in portions. The reaction was stirred overnight under $\mathrm{N}_{2}(\mathrm{~g})$ at room temperature. The solvent was removed by evaporation and the residue was taken up in $\mathrm{CHCl}_{3}$. The compound was purified by silica column chromatography $\left(\mathrm{CHCl}_{3}\right.$ with $\left.0-3 \% \mathrm{MeOH}\right)$ to yield a colorless oil which crystallized upon cooling at $4{ }^{\circ} \mathrm{C}(630 \mathrm{mg}, 84 \%) .{ }^{1} \mathrm{HNMR}\left(\mathrm{CDCl}_{3}, 400 \mathrm{MHz}, 25{ }^{\circ} \mathrm{C}\right): \delta$ $2.23\left(\mathrm{~s}, 3 \mathrm{H}\right.$, pyrone- $\left.\mathrm{CH}_{3}\right), 3.70\left(\mathrm{~s}, 3 \mathrm{H}\right.$, methoxy- $\left.\mathrm{CH}_{3}\right), 4.30(\mathrm{~d}, J=5.6 \mathrm{~Hz}, 2 \mathrm{H}), 5.19$ (s, 2H, benzyl- $\left.\mathrm{CH}_{2}\right), 6.15(\mathrm{~s}, 1 \mathrm{H}$, pyrone-H), $6.75(\mathrm{~d}, J=8.8 \mathrm{~Hz}, 2 \mathrm{H}), 7.05(\mathrm{~d}, J=8.4 \mathrm{~Hz}$,

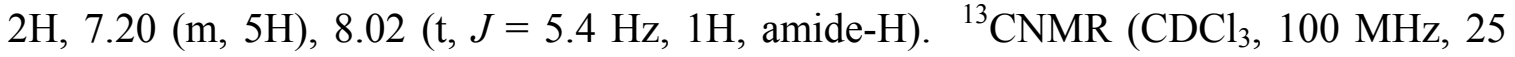
$\left.{ }^{\circ} \mathrm{C}\right): \quad \delta 19.5,42.8,54.9,74.5,113.6,114.8,128.2,128.4,128.6,128.8,128.9,134.7$, 145.1, 146.2, 158.2, 158.5, 165.1, 175.4. ESI-MS(+): $m / z 402.05[\mathrm{M}+\mathrm{Na}]^{+}$.

\section{3-Hydroxy-6-methyl-pyran-4(1H)-one-2-carboxy-N-[4-methoxybenzylamide)]}

(AM-4). AM-4P (120 mg, $0.32 \mathrm{mmol})$ was dissolved in $7.3 \mathrm{~mL}$ of a 1:1 solution of concentrated $\mathrm{HCl}$ and glacial acetic acid. The solution was stirred under $\mathrm{N}_{2}(\mathrm{~g})$ for $24 \mathrm{~h}$ at room temperature. The reaction was co-evaporated with methanol $(2 \times 20 \mathrm{~mL})$, and dried under vacuum to yield a crude off-white solid, which was recrystallized from EtOH (55 mg, 60\%). ${ }^{1} \mathrm{HNMR}\left(\mathrm{CDCl}_{3}, 400 \mathrm{MHz}, 25{ }^{\circ} \mathrm{C}\right): \delta 2.31\left(\mathrm{~s}, 3 \mathrm{H}\right.$, pyrone- $\left.\mathrm{CH}_{3}\right), 3.80(\mathrm{~s}, 3 \mathrm{H}$, methoxy- $\left.\mathrm{CH}_{3}\right), 4.55(\mathrm{~d}, J=6.0 \mathrm{~Hz}, 2 \mathrm{H}), 6.24(\mathrm{~s}, 1 \mathrm{H}$, pyrone-H), $6.88(\mathrm{~d}, J=8.4 \mathrm{~Hz}, 2 \mathrm{H})$, 
$7.20\left(\mathrm{br}, 1 \mathrm{H}\right.$, amide-H), $7.28(\mathrm{~d}, J=8.8 \mathrm{~Hz}, 2 \mathrm{H}) \cdot{ }^{13} \mathrm{CNMR}\left(\mathrm{CDCl}_{3}, 100 \mathrm{MHz}, 25{ }^{\circ} \mathrm{C}\right): \delta$ $20.2,43.0,55.3,113.1,114.1,128.7,129.3,132.4,148.2,159.1,174.0,181.0$. HRFABMS Calcd for $\mathrm{C}_{15} \mathrm{H}_{16} \mathrm{NO}_{5}$ : 290.1023. Found: 290.1022. Anal. Calcd for $\mathrm{C}_{15} \mathrm{H}_{15} \mathrm{NO}_{5}:$ C, 62.28; H, 5.23; N, 4.84. Found: $\mathrm{C}, 61.89 ; \mathrm{H}, 5.16 ; \mathrm{N}, 4.95$.

\section{3-Benzyloxy-6-methyl-pyran-4(1H)-one-2-carboxy-N-(4,4-}

cyanophenylbenzylamide) (AM-5P). To a solution of 2 (300 $\mathrm{mg}, 0.63 \mathrm{mmol})$ in toluene $(20 \mathrm{~mL})$ and $2 \mathrm{M}$ aqueous $\mathrm{K}_{2} \mathrm{CO}_{3}(20 \mathrm{~mL})$ was added 4-cyanophenylboronic acid (139 mg, $0.95 \mathrm{mmol}), \operatorname{Pd}\left(\mathrm{C}_{2} \mathrm{H}_{3} \mathrm{O}_{2}\right)_{2}(28 \mathrm{mg} 0.13 \mathrm{mmol})$, and $\mathrm{PPh}_{3}(34 \mathrm{mg}, 0.13 \mathrm{mmol})$. The reaction was heated to reflux at $135{ }^{\circ} \mathrm{C}$ under $\mathrm{N}_{2}$ (g) for 10 days. The reaction was extracted with $3 \times 30 \mathrm{~mL}$ toluene and the organic layer was washed with $30 \mathrm{~mL}$ water. The organic layer was dried over anhydrous $\mathrm{MgSO}_{4}$ and filtered. The resulting filtrate was evaporated to yield a light yellow solid. The product was purified by silica column chromatography $\left(\mathrm{CH}_{2} \mathrm{Cl}_{2}\right.$ with $\left.0-1 \% \mathrm{MeOH}\right)$ to yield an off-white solid (100 mg, $\left.40 \%\right)$. ${ }^{1} \mathrm{HNMR}\left(\mathrm{CDCl}_{3}, 400 \mathrm{MHz}, 25^{\circ} \mathrm{C}\right): \delta 2.35\left(\mathrm{~s}, 3 \mathrm{H}\right.$, pyrone- $\left.\mathrm{CH}_{3}\right), 4.45(\mathrm{~d}, J=6.0 \mathrm{~Hz}, 2 \mathrm{H})$, $5.33\left(\mathrm{~s}, 2 \mathrm{H}\right.$, benzyl- $\left.\mathrm{CH}_{2}\right), 6.27(\mathrm{~s}, 1 \mathrm{H}$, pyrone-H), $7.23(\mathrm{~m}, 7 \mathrm{H}), 7.50(\mathrm{~d}, J=8.0 \mathrm{~Hz}, 2 \mathrm{H})$,

$7.64(\mathrm{~d}, J=8.0 \mathrm{~Hz}, 2 \mathrm{H}), 7.71(\mathrm{~d}, J=8.4 \mathrm{~Hz}, 2 \mathrm{H}), 8.13(\mathrm{br}, 1 \mathrm{H}$, amide- $\mathrm{H}) .{ }^{13} \mathrm{CNMR}$ $\left(\mathrm{CDCl}_{3}, 100 \mathrm{MHz}, 2{ }^{\circ} \mathrm{C}\right): \delta 20.0,43.3,75.2,110.9,115.3,118.7,127.4,127.5,128.5$, 128.6, 128.9, 129.0, 132.5, 137.7, 138.3, 144.8, 145.9, 158.9, 165.6, 175.8. ESI-MS(+): $m / z 473.13[\mathrm{M}+\mathrm{Na}]^{+}$.

\section{3-Hydroxy-6-methyl-pyran-4(1H)-one-2-carboxy-N-(4,4-}

cyanophenylbenzylamide) (AM-5). To a solution of AM-5P (75 mg, $0.17 \mathrm{mmol})$ in 
methanol $(80 \mathrm{~mL})$ was added $10 \% \mathrm{Pd} / \mathrm{C}(8 \mathrm{mg}, 10 \% \mathrm{w} / \mathrm{w})$. The reaction was placed under $\mathrm{H}_{2}(\mathrm{~g})$ at $35 \mathrm{psi}$ for $20 \mathrm{~h}$. The catalyst was removed by filtration, and the resulting filtrate was evaporated to a white solid (40 mg, 62\%). ${ }^{1} \mathrm{HNMR}\left(\mathrm{CDCl}_{3}, 400 \mathrm{MHz}, 25\right.$ $\left.{ }^{\circ} \mathrm{C}\right): \delta 2.36\left(\mathrm{~s}, 3 \mathrm{H}\right.$, pyrone- $\left.\mathrm{CH}_{3}\right), 4.71(\mathrm{~d}, J=6.0 \mathrm{~Hz}, 2 \mathrm{H}), 6.29(\mathrm{~s}, 1 \mathrm{H}$, pyrone-H), 7.23 (br, 1H, amide-H), 7.47 (d, $J=8.4 \mathrm{~Hz}, 2 \mathrm{H}), 7.60$ (d, $J=8.0 \mathrm{~Hz}, 2 \mathrm{H}), 7.67$ (d, $J=8.0 \mathrm{~Hz}$, 2H), $7.74(\mathrm{~d}, J=8.4 \mathrm{~Hz}, 2 \mathrm{H}) .7 .41(\mathrm{~m}, 4 \mathrm{H}), 7.47(\mathrm{~m}, 4 \mathrm{H}), 7.56(\mathrm{~m}, 3 \mathrm{H}) .{ }^{13} \mathrm{CNMR}$ $\left(\mathrm{CDCl}_{3}, 100 \mathrm{MHz}, 25^{\circ} \mathrm{C}\right): \delta 19.6,42.6,110.3,112.6,118.5,127.1,127.3,128.1,132.3$, 136.0, 137.7, 138.0, 144.8, 147.7, 147.8, 162.8, 165.1. HR-FABMS Calcd for $\mathrm{C}_{21} \mathrm{H}_{17} \mathrm{~N}_{2} \mathrm{O}_{4}$ : 361.1183. Found: 361.1188. Anal. Calcd for $\mathrm{C}_{21} \mathrm{H}_{16} \mathrm{~N}_{2} \mathrm{O}_{4} \cdot 1.5 \mathrm{H}_{2} \mathrm{O}$ C, 65.11; H, 4.94; N, 7.23. Found: C, 64.95; H, 4.88; N, 6.87.

\section{3-Benzyloxy-6-methyl-pyran-4(1H)-one-2-carboxy-N-(4,4-biphenylbenzylamide)}

(AM-6P). To a solution of $2(200 \mathrm{mg}, 0.42 \mathrm{mmol})$ in toluene $(20 \mathrm{~mL})$ and $2 \mathrm{M}$ aqueous $\mathrm{K}_{2} \mathrm{CO}_{3}(20 \mathrm{~mL})$ was added 4-biphenylboronic acid (83 mg, $\left.0.42 \mathrm{mmol}\right), \operatorname{Pd}\left(\mathrm{C}_{2} \mathrm{H}_{3} \mathrm{O}_{2}\right)_{2}$ (9.2 $\mathrm{mg} 0.04 \mathrm{mmol})$, and $\mathrm{PPh}_{3}(11 \mathrm{mg}, 0.04 \mathrm{mmol})$. The reaction was heated to reflux at $135{ }^{\circ} \mathrm{C}$ under $\mathrm{N}_{2}(\mathrm{~g})$ for $24 \mathrm{~h}$. The reaction was extracted with $3 \times 30 \mathrm{~mL}$ toluene and the organic layer was washed with $30 \mathrm{~mL}$ water. The organic layer was dried over anhydrous $\mathrm{MgSO}_{4}$ and filtered. The resulting filtrate was evaporated to yield a yellow solid. The product was purified by silica column chromatography $\left(\mathrm{CHCl}_{3}\right.$ with $0-5 \%$ $\mathrm{MeOH})$ to an off-white solid (180mg, 85\%). ${ }^{1} \mathrm{HNMR}\left(\mathrm{CDCl}_{3}, 400 \mathrm{MHz}, 25{ }^{\circ} \mathrm{C}\right): \delta 2.38$ (s, 3H, pyrone- $\left.\mathrm{CH}_{3}\right), 4.48(\mathrm{~d}, J=6.0 \mathrm{~Hz}, 2 \mathrm{H}), 5.35\left(\mathrm{~s}, 2 \mathrm{H}\right.$, benzyl- $\left.\mathrm{CH}_{2}\right), 6.29(\mathrm{~s}, 1 \mathrm{H}$, pyrone-H), $7.23(\mathrm{~m}, 7 \mathrm{H}), 7.38(\mathrm{t}, J=8.4 \mathrm{~Hz}, 1 \mathrm{H}), 7.46(\mathrm{t}, J=8.0 \mathrm{~Hz}, 2 \mathrm{H}), 7.58(\mathrm{~d}, J=$

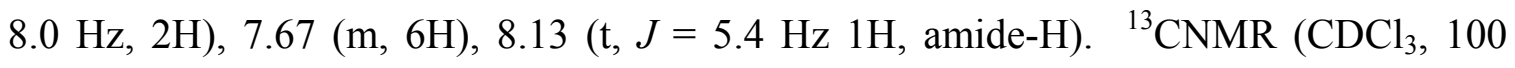


$\left.\mathrm{MHz}, 25^{\circ} \mathrm{C}\right): \quad \delta 20.1,43.6,75.2,115.3,126.9,127.2,127.3,127.4,128.4,128.7,129.0$ 129.1, 131.2, $135.0136 .2,139.3,140.0,140.1,140.4,159.0,165.6,175.9 . \quad$ ESI-MS(+): $m / z 523.98[\mathrm{M}+\mathrm{Na}]^{+}$.

\section{3-Hydroxy-6-methyl-pyran-4(1H)-one-2-carboxy-N-(4,4-biphenylbenzylamide)}

(AM-6). To AM-6P (160 mg, $0.32 \mathrm{mmol})$ was added $5 \mathrm{~mL}$ of a $1: 1$ solution of concentrated $\mathrm{HCl}$ and glacial acetic acid. The suspension was stirred under $\mathrm{N}_{2}(\mathrm{~g})$ for 24 $\mathrm{h}$ at room temperature. The reaction was co-evaporated with methanol $(2 \times 20 \mathrm{~mL})$, and dried under vacuum to yield a white solid (120 mg, 91\%). ${ }^{1} \mathrm{HNMR}\left(\mathrm{CDCl}_{3}, 400 \mathrm{MHz}\right.$, $\left.25^{\circ} \mathrm{C}\right): \delta 2.35\left(\mathrm{~s}, 3 \mathrm{H}\right.$, pyrone- $\left.\mathrm{CH}_{3}\right), 4.70(\mathrm{~d}, J=5.6 \mathrm{~Hz}, 2 \mathrm{H}), 6.28(\mathrm{~s}, 1 \mathrm{H}$, pyrone-H), 7.14 (br, 1H, amide-H), 7.25 (m, 3H), 7.37 (t, $J=7.4 \mathrm{~Hz}, 1 \mathrm{H}), 7.46$ (t, $J=8.4 \mathrm{~Hz}, 3 \mathrm{H})$,

$7.67(\mathrm{~m}, 6 \mathrm{H}) .{ }^{13} \mathrm{CNMR}\left(\mathrm{CDCl}_{3}, 100 \mathrm{MHz}, 25{ }^{\circ} \mathrm{C}\right): \quad \delta 20.4,43.3,113.1,126.9,127.2$, $127.3,127.4,127.5,128.4,128.7,135.3,135.8,139.1140 .2,140.3,148.1,140.4,162.9$, 164.3, 173.9. HR-FABMS Calcd for $\mathrm{C}_{26} \mathrm{H}_{22} \mathrm{NO}_{4}$ : 412.1543. Found: 412.1548. Anal. Calcd for $\mathrm{C}_{26} \mathrm{H}_{21} \mathrm{NO}_{4}{ }^{\bullet} 0.9 \mathrm{H}_{2} \mathrm{O}:$ C, 73.08; $\mathrm{H}, 5.26 ; \mathrm{N}, 3.06$. Found: C, 73.02; H, 5.37; N, 3.28 .

Recombinant MMP Assays. Activities of E. coli recombinant human MMP-1 catalytic domain (amino acids 81-249, $19.9 \mathrm{kDa}$ ), MMP-2 catalytic domain (amino acids 81-423, $40 \mathrm{kDa}$ ), and MMP-3 catalytic domain (amino acids 83-255, $19.5 \mathrm{kDa}$ ) were measured utilizing a 96-well microplate fluorescent assay kit purchased from BIOMOL International, following the procedure provided with the kit. Experiments were performed using a Bio-Tek Flx 800 fluorescence plate reader and Nunc white 96-well 
plates. The inhibitors (Figure 1) were dissolved in DMSO and further diluted 500-fold in assay buffer: $50 \mathrm{mM}$ HEPES, $10 \mathrm{mM} \mathrm{CaCl}$, 0.05\% Brij-35, pH 7.5 (MMP-1 and MMP2) and $50 \mathrm{mM}$ MES, $10 \mathrm{mM} \mathrm{CaCl}_{2}, 0.05 \%$ Brij-35, $\mathrm{pH} 6.0$ (MMP-3). MMP-1, MMP-2 and MMP-3 were incubated individually with varying concentrations of different inhibitors for $1 \mathrm{~h}$ at $37^{\circ} \mathrm{C}$, followed by addition of substrate to initiate the assay. Reactions were agitated by shaking for $1 \mathrm{sec}$ after each fluorescence measurement. Upon cleavage of the fluorescent substrate, Mca-Pro-Leu-Gly-Leu-Dpa-Ala-Arg-NH $\mathrm{N}_{2}(0.4 \mathrm{mM}$ in assay; Mca = 7-methoxycoumarin-4-yl)-acetyl; Dpa = N-3-(2,4-dinitrophenyl)-L- $\alpha-\beta$ diaminopropionyl) at the Gly-Leu bond, Mca fluorescence $\left(\lambda_{\mathrm{ex}}=340 \mathrm{~nm}, \lambda_{\mathrm{em}}=400 \mathrm{~nm}\right)$ was measured at 60 -second intervals for $20 \mathrm{~min}$. Experiments were repeated at least three times. $\mathrm{IC}_{50}$ values were calculated as the inhibitor concentration at which the enzyme is at $50 \%$ control activity (no inhibitor present).

Computational Methods. PDB structures 1G4K (MMP-3) and 1QIB (MMP-2) were used for docking with LUDI version 60a, as part of the InsightII 2000L framework. Calculations were run a dual-processor Xeon $2 \mathrm{GHz}$ Linux workstation. For structures having more than one protein in the asymmetric unit, the "A" chain was selected. Proteins were protonated using the "Hydrogens" command of the Biopolymer module of InsightII. Crystal waters and inhibitors were removed from each structure. The zinc binding group (ZBG) 3-hydroxy-2-methyl-4-pyrone (maltol) was positioned in the active site of each protein based on crystal structure coordinates of maltol bound to $\left[\left(\mathrm{Tp}^{\mathrm{Ph}, \mathrm{Me}}\right) \mathrm{ZnOH}\right]\left(\mathrm{Tp}^{\mathrm{Ph}, \mathrm{Me}}=\right.$ hydrotris(3,5-phenylmethylpyrazolyl)borate), a model of the zinc(II) ion coordination in the MMP active site (D.T. Puerta, S.M. Cohen, Inorg. Chem. 
2002, 41, 5075 and D.T. Puerta, J.R. Schames, R.H. Henchman, J.A. McCammon, S.M. Cohen, Angew. Chem. Int. Ed. 2003, 42, 3772). Positioning was performed by minimizing RMSD between the protein and model compound for the active site zinc ion and coordinating nitrogen atoms. Due to the rotational symmetry of the model compound, three alignments are possible. One of the alignments results in steric clashes with the protein backbone. A second alignment directed the P1' substitutent away from the appropriate ( $\mathrm{S} 1$ ') subsite. Only the third alignment allows the R groups (see Scheme 1) access to the S1' pocket (D.T. Puerta, S.M. Cohen, Inorg. Chem. 2002, 41, 5075); this alignment was used in all docking studies. Hydrogen atoms were added to the aligned maltol molecule and an amide group was built at the 2-position of the ring using Cerius ${ }^{2}$ 4.8.1.

All docking was performed using LUDI link mode, where docked fragments are constrained such that a methyl group on the fragment must be aligned with a link site. The N-H amide bonds on the maltol ZBG were selected as the link sites. Initial docking used the default LUDI link library of fragments, and the following parameters: maximum alignment angle $20^{\circ}$; maximum alignment RMSD $0.6 \AA$; search radius $11 \AA$; rotate bonds two at a time; preselect 4.0; minimum separation 3.0; lipophilic density 40; polar density 40; minimum surface 0 ; link weight 1.0 ; lipophilic weight 1.0 ; $\mathrm{H}$-bond weight 1.0; aliphatic aromatic off; reject bifurcated off; no unpaired polar off; electrostatic check off; minimum score 0; maximum fits 8000; maximum hits all; maximum unfilled cavity 0; energy estimate 1 scoring function (H.J. Böhm, J. Comp. Aided Molec. Design. 1994, 8, 623); and best fit. These parameters were chosen to maximize the quality and thoroughness of the docking. Despite this, it was found that 
results were somewhat dependent on the search sphere center, and favorable fragment poses could be missed with some search sphere centers, particularly for the larger fragments. To minimize this problem, multiple dockings were performed using different search sphere centers within the S1' pocket; the results presented represent the union of these results.

Further docking was performed using a custom link library consisting of the substituents illustrated in Scheme 1. Due to the limited ability of LUDI to handle rotational flexibility in fragments (only $120^{\circ}$ or $180^{\circ}$ rotations can be performed), all possible rotamers with $30^{\circ}$ increments of rotation were generated for each substituent, and each rotamer was added to the library as a separate fragment. The number of rotamers generated varied from 1 (no rotatable bonds) to 72 conformations, depending the on the number of rotatable bonds in each individual fragment. Portions of the fragment with two-fold rotational symmetry were rotated through $180^{\circ}$; asymmetric portions were rotated through $360^{\circ}$. Bonds between phenyl groups were treated as nonrotatable, and rotamers with steric clashes or eclipsed conformations were excluded. Docking with this custom library was performed using the same parameters as above, except bond rotation was set to one at a time. It would seem that because the library already included all rotamers, bond rotation could be set to none, but using one at a time seemed to reduce the differences in results caused by using different search sphere centers.

Reported LUDI scores (Table S1) represent the highest scoring pose for a fragment in the specified protein structure, rounded to the nearest 10. Higher scores indicate higher 
predicted affinity, with each 100 points representing a predicted order of magnitude decrease in $\mathrm{IC}_{50}$.

Cell Invasion Assay. A cell invasion assay kit was purchased from Chemicon International (Cat. No. ECM 555) and was performed as per kit instructions with minor modifications. Rat cardiac fibroblasts (CF) were prepared as previously described (F.J. Villarreal, N.N. Kim, G.D. Ungab, M.P. Printz, W.H. Dillmann, Circulation 1993, 88, 2849). Briefly, CF were prepared from hearts of 1-2 day old Sprague Dawley rats. Following collagenase digestions (4×), non-myocyte cells (mostly fibroblasts) were isolated by Percoll density gradient. The cell suspension was plated onto uncoated tissue culture dishes for 30 min to allow preferential attachment of CF to the bottom of the dish. The non-adherent cells were removed and fresh media (Dulbecco's modified Eagle's media $+10 \%$ fetal bovine serum) was added. $\mathrm{CF}$ were allowed to proliferate to confluence and then trypsinized and frozen at $-70{ }^{\circ} \mathrm{C}$. Stocks were freshly plated for the experiment and used from second passage. When reaching 90\% confluence, cells were serum deprived for $24 \mathrm{~h}$ and then treated according to the experimental design (vide infra).

The CF were trypsinized once more and suspended in fresh serum-free media. Inhibitors AM-5 and AM-6 were dissolved in DMSO and diluted 10-fold in serum free media. The inhibitor solution $(2 \mu \mathrm{L})$ was added to $100 \mu \mathrm{L}$ of the cell suspension. The cell suspension containing inhibitors was added to the upper chamber of the well. Media with $10 \%$ fetal bovine serum (as chemoattractant) was added to the lower chamber of the well. The plate was incubated for $20 \mathrm{~h}$ in a $\mathrm{CO}_{2}$ incubator $\left(10 \% \mathrm{CO}_{2}\right)$. The cells that had 
invaded into the lower chamber were dislodged from the underside of the ECMatrix ${ }^{\mathrm{TM}}$ membrane and lysed. The lysed cells were treated with CyQuant GR Dye, and monitored for fluorescence using a Bio-Tek Flx 800 fluorescence plate reader and Nunc white 96well plates $\left(\lambda_{\mathrm{ex}}=485 \mathrm{~nm}, \lambda_{\mathrm{em}}=516 \mathrm{~nm}\right)$. Increased fluorescence indicates the presence of invaded cells (Figure S1). 


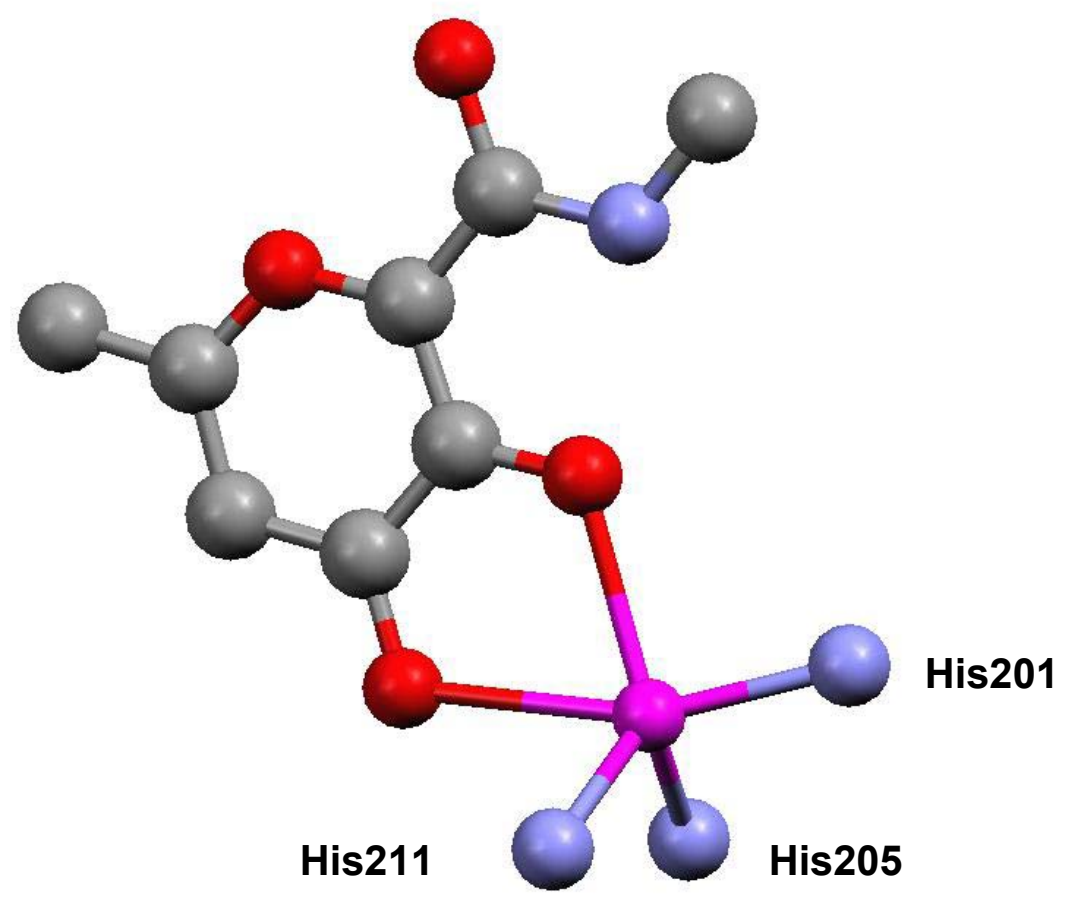

Figure S1. Ball-and-stick representation of the pyrone ZBG bound to the catalytic zinc(II) ion in MMP-3. This diagram illustrates the coordination environment on the zinc center used in the docking studies. The amide group on the ZBG was added in silico. The coordination geometry of the zinc(II) ion is slightly distorted trigonal bipyramidal with a $\tau$ value of 0.85 (Addison, A.W.; Rao, T.N.; Reedijk, J.; van Rijn, J.; Verschoor, G.C. J. Chem. Soc., Dalton Trans. 1984, 1349-1356). 

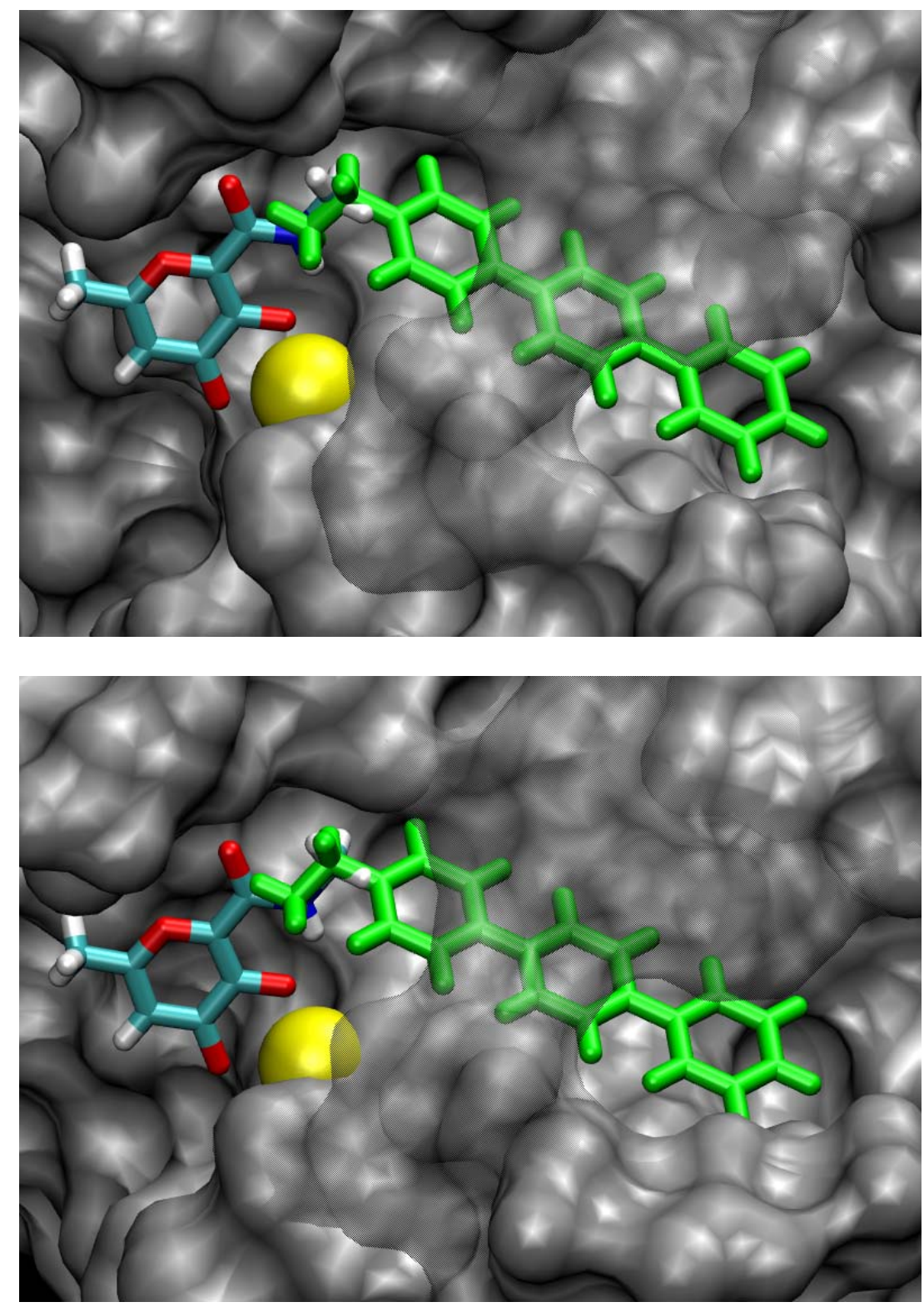

Figure S2. LUDI docking image of backbone fragment (green, in S1' subsite) with pyrone ZBG (colored by element) in the active site of MMP-2 (top) and MMP-3 (bottom). This fragment combination leads to the compound designated AM-6 (see Scheme 1). The zinc(II) ion is shown as a gold sphere. There are no interactions apparent in these docking experiments that explain the observed selective for MMP-3 over MMP-2 (similar results are obtained for AM-2 and AM-5). 


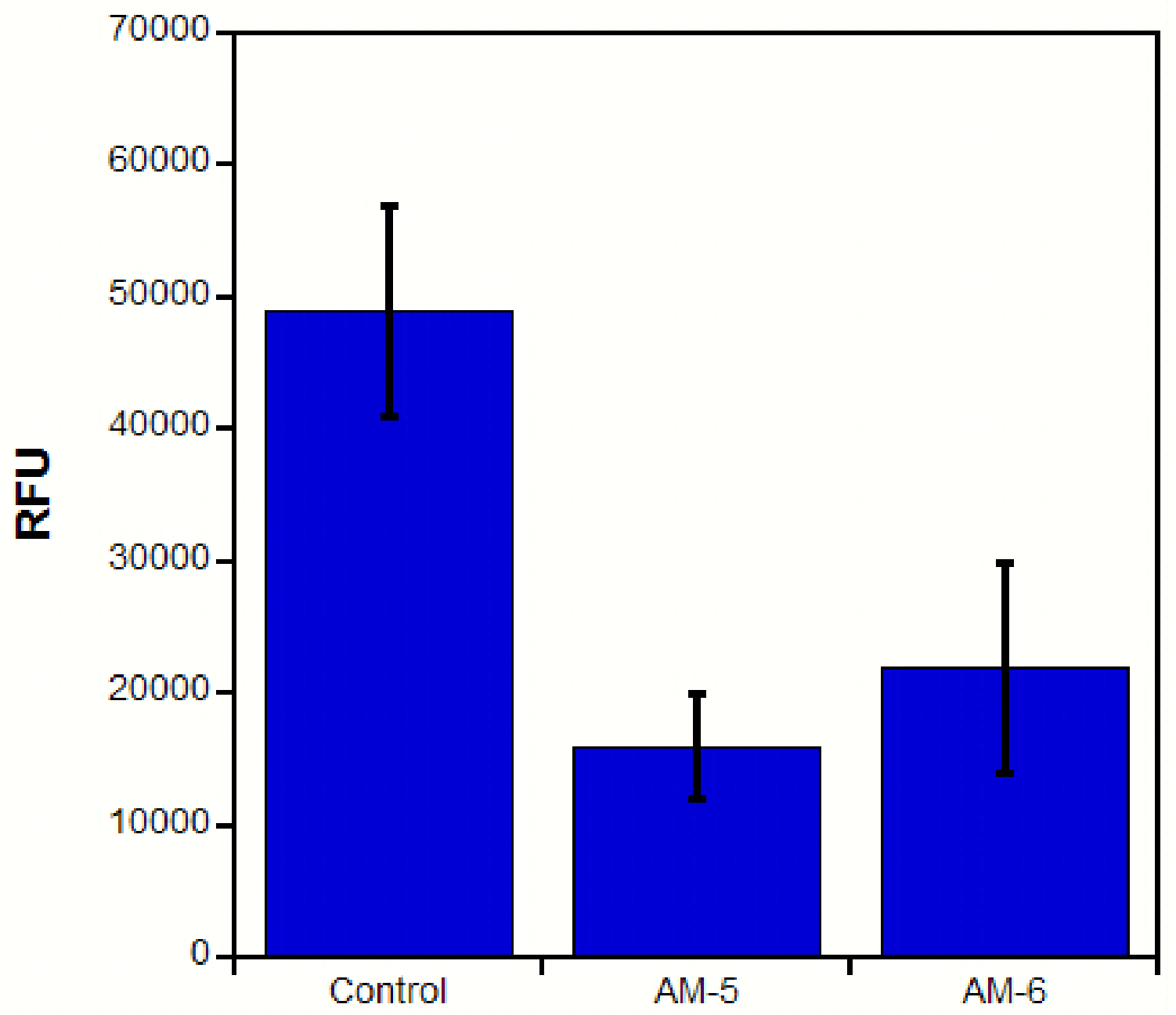

Figure S3. Neonatal cardiac fibroblast (CF) invasion assay results. Fluorescent measurement (in RFUs) of lysed cells after invasion with: no inhibitor (Control), $250 \mathrm{nM}$ AM-5, and 250 nM AM-6. Increased RFUs indicates increased cell invasion. 
Table S1. LUDI scores for Inhibitor Fragments in MMP-2 (1QIB) and MMP-3 $(1 \mathrm{G} 4 \mathrm{~K})$.

\begin{tabular}{|l|l|l|}
\hline Inhibitor & MMP-2 & MMP-3 \\
\hline AM-1 & NS & NS \\
\hline AM-2 & 530 & 600 \\
\hline AM-3 & NS & NS \\
\hline AM-4 & 440 & 440 \\
\hline AM-5 & 570 & 640 \\
\hline AM-6 & 690 & 700 \\
\hline
\end{tabular}

NS $=$ No Score, no acceptable conformations were found.

\section{References}

Complete Reference 5:

Hajduk, P. J.; Shuker, S. B.; Nettesheim, D. G.; Craig, R.; Augeri, D. J.; Betebenner, D.; Albert, D. H.; Guo, Y.; Meadows, R. P.; Xu, L.; Michaelides, M.; Davidsen, S. K.; Fesik, S. W., J. Med. Chem. 2002, 45, 5628-5639.

Complete Reference 13:

Hajduk, P. J.; Sheppard, G.; Nettesheim, D. G.; Olejniczak, E. T.; Shuker, S. B.; Meadows, R. P.; Steinman, D. H.; Carrerea Jr., G. M.; Marcotte, P. A.; Severin, J.; Walter, K.; Smith, H.; Gubbins, E.; Simmer, R.; Holzman, T. F.; Morgan, D. W.; Davidsen, S. K.; Summers, J. B.; Fesik, S. W., J. Am. Chem. Soc. 1997, 119, 5818-5827. 